\title{
Proteomic analysis of post-nuclear supernatant fraction and percoll-purified membranes prepared from brain cortex of rats exposed to increasing doses of morphine
}

Hana Ujcikova ${ }^{1}$, Adam Eckhardt ${ }^{2}$, Dmytro Kagan ${ }^{1}$, Lenka Roubalova ${ }^{1}$ and Petr Svoboda ${ }^{1{ }^{*}}$

\begin{abstract}
Background: Proteomic analysis was performed in post-nuclear supernatant (PNS) and Percoll-purified membranes (PM) prepared from fore brain cortex of rats exposed to increasing doses of morphine (10-50 mg/kg) for 10 days.

Results: In PNS, the 10 up ( $\uparrow$ )- or down $(\downarrow)$-regulated proteins exhibiting the largest morphine-induced change were selected, excised manually from the gel and identified by MALDI-TOF MS/MS: 1-(gi|148747414, Guanine deaminase), $\uparrow 2.5 x$; 2-(gi|17105370, Vacuolar-type proton ATP subunit B, brain isoform), $\uparrow 2.6 x ; 3$-(gi|1352384, Protein disulfide-isomerase A3), $\uparrow 3.4 x ; 4-(g i \mid 40254595$, Dihydropyrimidinase-related protein 2), $\uparrow 3.6 x ; 5$-(gi|149054470, N-ethylmaleimide sensitive fusion protein, isoform CRAa), $\uparrow 2.0 x$; 6-(gi|42476181, Malate dehydrogenase, mitochondrial precursor), $\uparrow 1.4 x ; 7$-(gil 62653546, Glyceraldehyde-3-phosphate dehydrogenase), 1 1.6x; 8-(gi|202837, Aldolase A), $\uparrow 1.3 x ; 9$-(gi|31542401, Creatine kinase B-type), $\downarrow 0.86 \times ;$ 10-(gi|40538860, Aconitate hydratase, mitochondrial precursor), $\uparrow 1.3 \times$. The identified proteins were of cytoplasmic $(1,4,5,7,9)$, cell membrane (2), endoplasmic reticulum (3) and mitochondrial $(6,8,10)$ origin and 9 of them were significantly increased, 1.3-3.6x. The 4 out of 9 up-regulated proteins $(4,6,7,10)$ were described as functionally related to oxidative stress; the 2 proteins participate in genesis of apoptotic cell death.

In PM, the 18 up ( $\uparrow$ )- or down ( $\downarrow$ )-regulated proteins were identified by LC-MS/MS and were of plasma membrane [Brain acid soluble protein, $\downarrow 2.1 \times$; trimeric G $\beta$ subunit, $\downarrow 2.0 x]$, myelin membrane $[\mathrm{MBP}, \downarrow 2.5 \times$ ], cytoplasmic [Internexin, $\uparrow 5.2 \times$; DPYL2, $\uparrow 4.9 x ;$ U Ubiquitin hydrolase, $\downarrow 2.0 x ; 605$ ribosomal protein, $\uparrow 2.7 x ; \mathrm{KCRB}, \downarrow 2.6 x ;$ Sirtuin-2, $\uparrow 2.5 x$; Peroxiredoxin-2, $\uparrow 2.2 x ;$ Septin-11, $\uparrow 2.2 x_{;}$TERA, $\uparrow 2.1 x_{;}$SYUA, $\uparrow 2.0 x ;$ Coronin-1 A, $\downarrow 5.4 X$ ] and mitochondrial [Glutamate dehydrogenase 1,

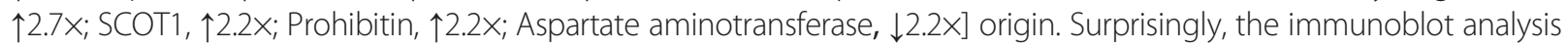
of the same PM resolved by 2D-ELFO indicated that the "active", morphine-induced pool of G $\beta$ subunits represented just a minor fraction of the total signal of $\mathrm{G} \beta$ which was decreased 1.2x only. The dominant signal of $\mathrm{G} \beta$ was unchanged.
\end{abstract}

Conclusion: Brain cortex of rats exposed to increasing doses of morphine is far from being adapted. Significant up-regulation of proteins functionally related to oxidative stress and apoptosis suggests a major change of energy metabolism resulting in the state of severe brain cell "discomfort" or even death.

Keywords: Morphine, Long-term adaptation, Fore brain cortex, Isolated plasma membranes, Post-nuclear supernatant, $2 \mathrm{D}$ electrophoresis

\footnotetext{
* Correspondence: svobodap@biomed.cas.cz

'Laboratories of Biochemistry of Membrane Receptors, Institute of Physiology, v.vi.i., Academy of Sciences of the Czech Republic, Videnska 1083, Prague 4 14220, Czech Republic

Full list of author information is available at the end of the article
} 


\section{Background}

Morphine is one of the most effective painkillers. Repeated exposure of experimental animals to morphine results in tolerance to this drug, development of physical dependence and a chronic relapsing disorder - drug addiction [1-5]. Physical dependence contributes to a drug seeking behavior and the continuous drug use with the aim to prevent the onset of unpleasant withdrawal symptoms. To name just few, morphine-induced changes of brain function were associated with alternations of synaptic connectivity [6], neurotransmission [7], specific signaling cascades [8], energy metabolism [9] and stability of protein molecules [10].

Hyper-sensitization or super-activation of adenyl cyclase (AC) activity by prolonged exposure of cultured cells or mammalian organism to morphine has been demonstrated in previous studies of mechanism of action of this drug [1-5] and considered as biochemical basis for development of opiate tolerance and dependence.

Our previous work on isolated Percoll $^{\circledR}$ membranes (PM) prepared from brain cortex of rats exposed to morphine for 10 days $(10-50 \mathrm{mg} / \mathrm{kg})$ indicated a desensitization of Gprotein response to $\mu$-OR (DAMGO) and $\delta$-OR (DADLE) stimulation [11] and specific increase of ACI (8x) and ACII $(2.5 \times)$ isoforms [12]. The $\mathrm{k}-\mathrm{OR}(\mathrm{U}-23554)$-stimulated $\left[{ }^{35} \mathrm{~S}\right]$ GTPYS binding and expression level of ACIII-IX in PM was unchanged. Behavioral tests of morphine-treated animals indicated that these animals were fully drugdependent (opiate abstinence syndrome) and developed tolerance to subsequent drug addition (analgesic tolerance hot-plate and hind paw withdrawal tests). The increase of $\mathrm{ACI}$ and ACII was interpreted as a specific compensatory response to prolonged stimulation of brain cortex OR by morphine.

Proteomic analysis represents a useful approach for an investigation of the overall changes of protein composition induced by the short-term or prolonged use of drugs. The aim of our present work was to identify proteins which are significantly altered in brain cortex of rats exposed to the increasing, high doses of morphine for prolonged period of time (10 days). For this aim, the post-nuclear supernatant fraction (PNS) was analyzed because it contains proteins of mitochondrial, endoplasmic reticulum, plasma membrane as well as cytoplasmic origin. In the second part of our work, we extended these studies by analysis of protein composition in membrane fraction isolated in Percoll gradient (PM).

\section{Results}

Two-dimensional electrophoresis and protein identification in post-nuclear supernatant prepared from brain cortex of control and morphine-treated rats; analysis by MALDI-TOF MS/MS

Samples of PNS were extracted in ice-cold aceton/TCA/ $96 \%$ ethanol, resolved by 2 D-ELFO in linear IPG strips
(pH 3-11) and 10\% w/v acrylamide $/ 0.26 \% \mathrm{w} / \mathrm{v}$ bisacrylamide gels as described in methods and stained with silver or colloidal Coomassie blue. The stained 2D gels were scanned with an imaging densitometer and quantified by PDQuest software.

About 440 protein spots were recognized by silver staining and PDQuest analysis of gels in both types of PNS (Figure 1, left panels); when stained in colloidal Coomassie blue, about 200 spots were recognized. In CBB-stained gels, proteins 1-10 with different mobility in (+M10) and (-M10) samples were selected for identification by MALDI-TOF MS/MS as described in methods (Figure 1, right panels). The detailed list of the altered and identified proteins is presented in Additional file 1: Table S1 and Table 1. These tables also include description of the subcellular localization and function of these proteins.

The identified proteins were of cytoplasmic (1-Guanine deaminase, $\uparrow 2.5 \times$; 4-Dihydropyrimidinase-related protein 2,^3.6×; 5-N-ethylmaleimide sensitive fusion protein, isoform CRAa, $\uparrow 2.0 \times$; 7-Glyceraldehyde-3-phosphate dehydrogenase, $\uparrow 1.6 \times$; 9-Creatine kinase B-type, $\downarrow 0.86)$, cell membrane (2-Vacuolar-type proton ATPase, subunit B, brain isoform), $\uparrow 2.6 \mathrm{x}$ ), endoplasmic reticulum (3-Protein disulfide-isomerase $\mathrm{A} 3, \uparrow 3.4 \times$ ) and mitochondrial (6-Malate dehydrogenase, mitochondrial precursor, $\uparrow 1.4 \mathrm{x}$; 8-Aldolase A, $\uparrow 1.3 \times$; 10-Aconitate hydratase, mitochondrial precursor, $\uparrow 1.3 \mathrm{x})$ origin. The 9 of them were significantly increased, 1.3-3.6x. Correlation with functional properties of these proteins indicated up-regulation of proteins related to guanine degradation (1), vacuolar acidification (2), apoptotic cell death (3), oxidative stress $(4,6,7,10)$, membrane traffic (5) and glycolysis (8). All together, the spectrum of the altered proteins suggests a major alternation of brain cortex tissue when exposed to increasing doses of morphine. The most significant change from functional point of view was up-regulation of proteins related to oxidative stress (see discussion for further details).

\section{Two-dimensional electrophoresis and protein identification in Percoll-purified membranes isolated from brain cortex of control and morphine-treated rats; analysis by LC-MS/MS}

PM samples were resolved by 2D-electrophoresis in the same way as described for PNS. The resolution in $10 \% \mathrm{w} / \mathrm{v}$ acrylamide $/ 0.26 \% \mathrm{w} / \mathrm{v}$ bis-acrylamide gels was used in the case of silver staining; $12.0 \% \mathrm{w} / \mathrm{v}$ acrylamide/ $0.32 \% \mathrm{w} / \mathrm{v}$ bis-acrylamide gels were used for staining in CBB. About 300 protein spots were recognized by silver (Figure 2, left panels); when stained in CBB, the total number of detected protein spots was 490 (Figure 2, right panels). Proteins 1-18 with an altered mobility in $(+\mathrm{M} 10)$ versus $(-\mathrm{M} 10)$ samples were excised from in 


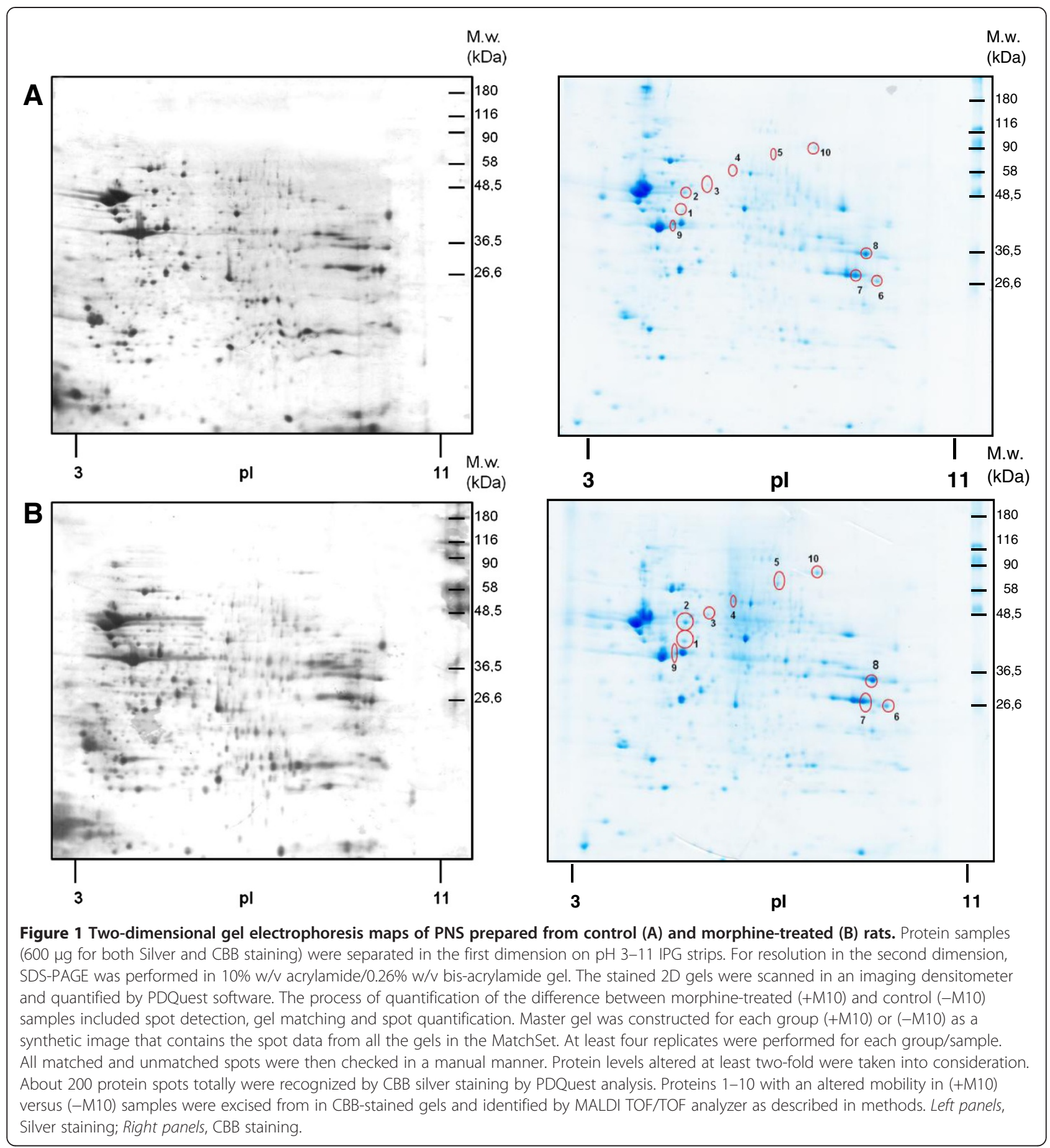

CBB-stained gels and identified by LC-MS/MS. The list of altered and identified proteins is presented in Additional file 2: Table S2 and Table 2. These tables also include a brief description of subcellular localization and function of these proteins as well as quantitative estimate of their relative change induced by morphinetreatment.

The identified up $(\uparrow)$ - or down $(\downarrow)$-regulated proteins were of plasma membrane [1-BASP1, Brain acid soluble protein 1, $\downarrow 2.1 \times ; 2$-GBB1, Guanine nucleotide-binding protein subunit beta-1, $\downarrow 2.0 \times]$, myelin membrane [17MBP, Myelin basic protein S, $\downarrow 2.5 \times$ ], cytoplasmic [3KCRB, Creatine kinase B-type (EC 2.7.3.2), $\downarrow 2.6 x$; 4-AINX, Alpha-internexin, $\uparrow 5.2 \times$; 5-DPYL2, Dihydropyrimidinaserelated protein $2, \uparrow 4.9 \times ; 6$-SIRT2, NAD-dependent deacetylase sirtuin-2, $\uparrow 2.5 \times$; 7-SYUA, Alpha-synuclein, $\uparrow 2.0 \times$; 8-PRDX2, Peroxiredoxin-2, $\uparrow 2.2 \times$; 9-TERA, Transitional endoplasmic reticulum ATPase, $\uparrow 2.1 \times$; 13-UCHL1, 
Table 1 Functional significance of proteins identified in PNS as altered by chronic morphine

\begin{tabular}{|c|c|c|c|c|}
\hline Protein name & $\begin{array}{l}\text { Change } \\
\text { (dependence } \\
\text { vs.control) }\end{array}$ & $\begin{array}{l}\text { Subcellular } \\
\text { localization }\end{array}$ & $\begin{array}{l}\text { Functional } \\
\text { category }\end{array}$ & Protein characterization - PNS \\
\hline Guanine deaminase & Up-regulated & Cytoplasm & Metabolism & Purine metabolism, guanine degradation [13] \\
\hline $\begin{array}{l}\text { V-type proton ATP } \\
\text { subunit B, brain isoform }\end{array}$ & Up-regulated & Cell membrane & Trafficking & ATP hydrolysis coupled proton transport, vacuolar acidification [14] \\
\hline $\begin{array}{l}\text { Protein disulfide- } \\
\text { isomerase A3 }\end{array}$ & Up-regulated & $\begin{array}{l}\text { Endoplasmatic } \\
\text { reticulum } \\
\text { lumen }\end{array}$ & $\begin{array}{l}\text { Cellular } \\
\text { development } \\
\text { and regulation }\end{array}$ & $\begin{array}{l}\text { Up-regulation of this protein causes apoptotic cell death [15], } \\
\text { alterations in its level were revealed during neurodegenerative } \\
\text { processes [16] }\end{array}$ \\
\hline $\begin{array}{l}\text { Dihydropyrimidinase- } \\
\text { related protein } 2\end{array}$ & Up-regulated & Cytoplasm & $\begin{array}{l}\text { Neuronal } \\
\text { development } \\
\text { and regulation }\end{array}$ & $\begin{array}{l}\text { Neuronal development and polarity [8], cone collapse and cell } \\
\text { migration; one of major determinants in the control of oxidative } \\
\text { stress [17] }\end{array}$ \\
\hline $\begin{array}{l}\text { N-ethylmaleimide } \\
\text { sensitive fusion protein, } \\
\text { isoform CRA_a }\end{array}$ & Up-regulated & Cytoplasm & Trafficking & $\begin{array}{l}\text { ATP binding, regulating protein membrane trafficking, involved in } \\
\text { vesicle priming [18] }\end{array}$ \\
\hline $\begin{array}{l}\text { Malate dehydrogenase, } \\
\text { mitochondrial precursor }\end{array}$ & Up-regulated & $\begin{array}{l}\text { Mitochondrion } \\
\text { matrix }\end{array}$ & Metabolism & $\begin{array}{l}\text { L-malate dehydrogenase activity, protein self-association; up- } \\
\text { regulation of the mitochondrial malate dehydrogenase is caused } \\
\text { by oxidative stress [19] }\end{array}$ \\
\hline $\begin{array}{l}\text { Glyceraldehyde-3- } \\
\text { phosphate } \\
\text { dehydrogenase }\end{array}$ & Up-regulated & Cytoplasm & Metabolism & $\begin{array}{l}\text { Glyceraldehyde-3-phosphate dehydrogenase and nitrosylase } \\
\text { activities; surprising role in apoptosis [20]; is known as a major } \\
\text { target protein in oxidative stress [21] }\end{array}$ \\
\hline Aldolase A & Up-regulated & Mitochondrion & Metabolism & $\begin{array}{l}\text { Role in glycolysis and gluconeogenesis, scaffolding protein; } \\
\text { potential role in regulating the free intracellular concentration of } \\
\text { InsP3, and subsequently intracellular calcium dynamics[22,23]; the } \\
\text { expression of aldolase A may be regulated by chronic lithium } \\
\text { administration [24] }\end{array}$ \\
\hline Creatine kinase B-type & $\begin{array}{l}\text { Down- } \\
\text { regulated }\end{array}$ & Cytoplasm & Metabolism & $\begin{array}{l}\text { Energy-related (skeletal muscle, heart, brain and spermatozoa), } \\
\text { brain development [25] }\end{array}$ \\
\hline $\begin{array}{l}\text { Aconitate hydratase, } \\
\text { mitochondrial precursor }\end{array}$ & Up-regulated & Mitochondrion & Metabolism & $\begin{array}{l}\text { Isomerization of citrate to isocitrate via cis-aconitate;an iron-sulfur } \\
\text { protein, the particular susceptibility to oxidative damage may be } \\
\text { related to the iron-sulfur cluster [4Fe-4S]in its active site [26] }\end{array}$ \\
\hline
\end{tabular}

Ubiquitin carboxyl-terminal hydrolase L1, $\downarrow 2.0 \times$; 15COR1A, Coronin-1A, $\downarrow 5.4 \times, 16-$ SEP11, Septin-11, $\uparrow 2.2 \times$; 18-RL12, 60S ribosomal protein L12, $\uparrow 2.7 \times]$ and mitochondrial [10-DHE3, Glutamate dehydrogenase 1, $\uparrow 2.7 \times$; 11-SCOT1, Succinyl-CoA:3-ketoacid-coenzyme A transferase $1, \uparrow 2.2 \times$; 12-AATM, Aspartate aminotransferase, $\downarrow 2.2 \times$; 14-PHB, Prohibitin, $\uparrow 2.2 \times]$ origin.

Thus, the only member of GPCR-initiated signaling cascades identified by LC-MS/MS was trimeric G $\beta$ subunit, which was decreased $2 \times$ in PM samples prepared from morphine-adapted rats. The morphine-induced decrease of G $\beta$ subunit in PM was subsequently verified by immunoblot analysis of the same 2D-gels as those used for preparation of samples for LC-MS/MS (Figure 3). The spot 2 (compare with Figure 2) represented just a small fraction of the total signal of G $\beta$ subunits which was distributed over wider range of $\mathrm{pI}$. The total signal of G $\beta$ was decreased $1.2 x$ only. We have divided the signal of $G \beta$ in CBB-stained gels into 8 small spots according to immunoblot signal (Figure 3) in order to verify it. Proteomic analysis was performed by LC-MS/MS and positive signal was detected in spots 3, 4, 5, 7 and 8 (Table 3).

Therefore, the decrease of G $\beta$ determined by proteomic analysis $(2 \times)$ has to be regarded as an alternation of relatively small fraction of numerous forms of $G \beta$ resolved by $2 \mathrm{D}$-ELFO. Morphine-induced decrease of $\mathrm{G} \beta$ is selectively oriented to specific, minority component of this protein; the dominant pool of $G \beta$ subunits is unchanged.

\section{Discussion}

Opium extracts from the plant Papaver somniferum have been used for therapeutic and recreational purposes for thousands of years. Opioid alkaloids and related pharmaceuticals are the most effective analgesics for the treatment of acute and chronic pain. They also represent one of the largest components of the illicit drug market worldwide, generating revenue of approximately $\$ 70$ billion in 2009, much of which supports crime, wars and terrorism. Intravenous use of opioid drugs is a leading cause of death by overdose in Europe and North America, and a major contributing factor to the worldwide AIDS epidemic [50,51].

Morphine and codeine are the main active opioid alkaloids in opium. In humans, they act on the central nervous system to produce a wide range of effects including analgesia, euphoria, sedation, respiratory depression and cough suppression. Chronic opiate administration results 


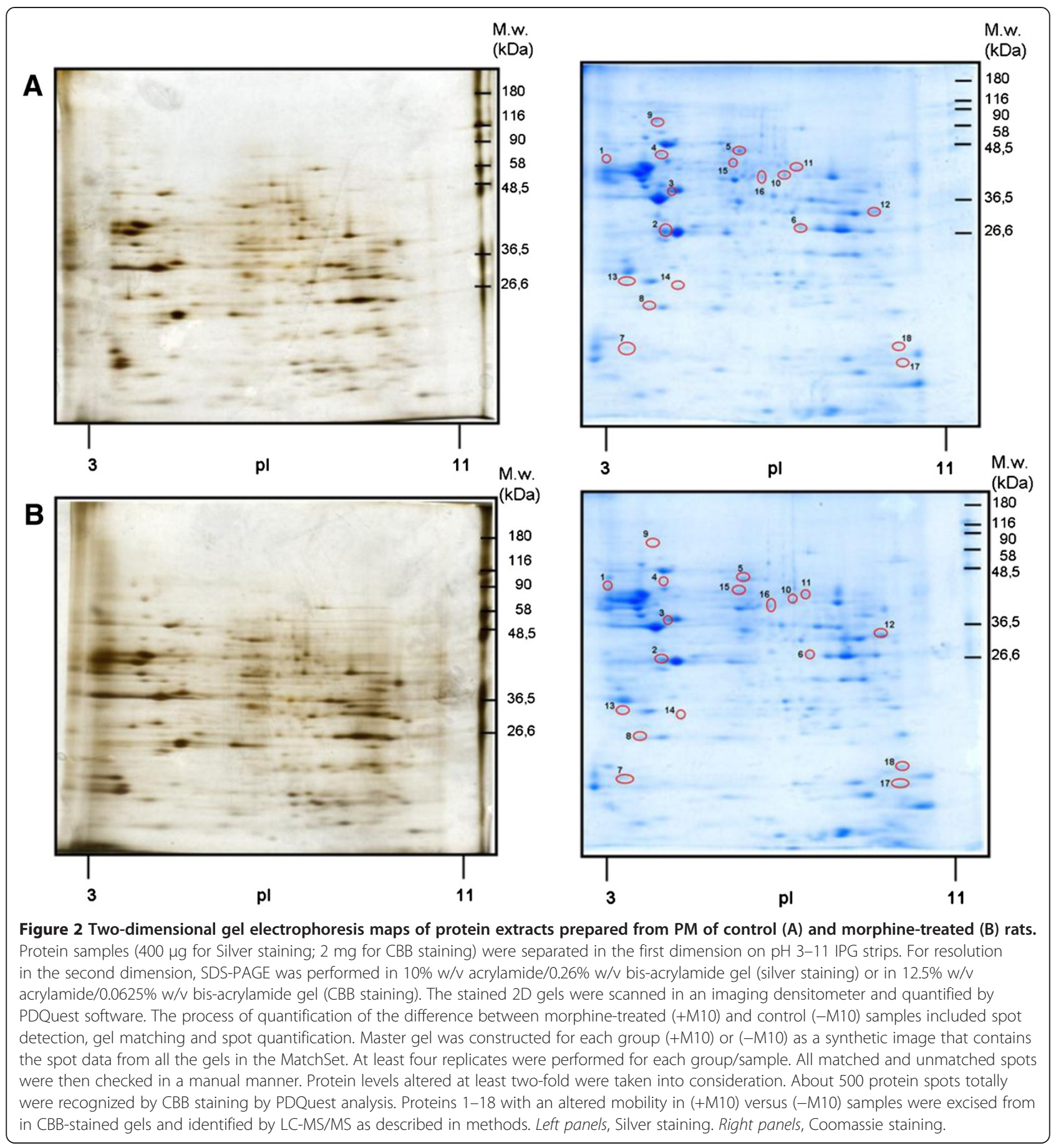

in the development of tolerance and dependence, but the regulation of MOR and DOR function during this process is not clearly understood.

To localize changes of MOR-stimulated G-protein activity in various brain regions after chronic morphine treatment, Sim et al. [52] examined $\left[{ }^{35} \mathrm{~S}\right] \mathrm{GTP} \gamma \mathrm{S}$ binding to brain sections by in vitro autoradiography. Rats were treated for $12 \mathrm{~d}$ with increasing doses $\left(10-320 \mathrm{mg} \cdot \mathrm{kg}^{-1}\right.$ . $\mathrm{d}^{-1}$ ) of morphine. Control rats were injected with either saline or a single acute injection of morphine $(20 \mathrm{mg} / \mathrm{kg})$. $\left[{ }^{35} \mathrm{~S}\right] \mathrm{GTP} \gamma \mathrm{S}$ binding was measured in the presence or absence of MOR-selective agonist DAMGO. In rats injected with a single acute dose of morphine, no significant changes were detected in basal or DAMGO-stimulated $\left[{ }^{35} \mathrm{~S}\right] \mathrm{GTP} \gamma \mathrm{S}$ binding in any brain region. In chronic morphine-treated rats, however, DAMGO-stimulated $\left[{ }^{35} \mathrm{~S}\right] \mathrm{GTP} \gamma \mathrm{S}$ binding in cerebral cortex was significantly decreased when compared with control rats. Similar data were obtained in analysis of 
Table 2 Functional significance of proteins identified in PM fraction as altered by chronic morphine

\begin{tabular}{|c|c|c|c|c|}
\hline Protein name & $\begin{array}{c}\text { Change } \\
\text { (dependence } \\
\text { vs.control) }\end{array}$ & $\begin{array}{l}\text { Subcellular } \\
\text { localization }\end{array}$ & Functional category & Protein characterization - PM \\
\hline $\begin{array}{l}\text { Brain acid soluble protein } \\
1\end{array}$ & $\begin{array}{l}\text { Down- } \\
\text { regulated }\end{array}$ & $\begin{array}{l}\text { Cell membrane; } \\
\text { Lipid anchor }\end{array}$ & $\begin{array}{l}\text { Neuronal } \\
\text { development and } \\
\text { regulation }\end{array}$ & $\begin{array}{l}\text { Associated with the membranes of growth cones that form } \\
\text { the tips of elongating axons, DNA-dependent, localizes in } \\
\text { the membrane raft domain with a cholesterol-dependent } \\
\text { manner; changes in the localization during the develop- } \\
\text { ment of neuronal polarity [27] }\end{array}$ \\
\hline
\end{tabular}

\begin{tabular}{|c|c|c|c|}
\hline $\begin{array}{l}\text { Guanine nucleotide- } \\
\text { binding protein subunit } \\
\text { beta-1 }\end{array}$ & $\begin{array}{l}\text { Down- } \\
\text { regulated }\end{array}$ & Cell membrane & Signaling \\
\hline Creatine kinase B-type & $\begin{array}{l}\text { Down- } \\
\text { regulated }\end{array}$ & Cytoplasm & Metabolism \\
\hline Alpha-internexin & Up-regulated & Cytoplasm & $\begin{array}{l}\text { Neuronal } \\
\text { development and } \\
\text { regulation }\end{array}$ \\
\hline $\begin{array}{l}\text { Dihydropyrimidinase- } \\
\text { related protein } 2\end{array}$ & Up-regulated & Cytoplasm & $\begin{array}{l}\text { Neuronal } \\
\text { development and } \\
\text { regulation }\end{array}$ \\
\hline $\begin{array}{l}\text { NAD-dependent } \\
\text { deacetylase sirtuin-2 }\end{array}$ & Up-regulated & Cytoplasm & $\begin{array}{l}\text { Cellular development } \\
\text { and regulation }\end{array}$ \\
\hline
\end{tabular}

$\mathrm{G} \beta 1$ is required for neural tube closure, neural progenitor cell proliferation and neonatal development [28]; stimulated ACII, ACIV, ACVII, inhibited ACI, ACVNNI, ACVIII [29,30]

Energy-related (skeletal muscle, heart, brain and spermatozoa), brain development [25], aging [31]; one of major determinants in the control of oxidative stress [17]

Copurifies with intermediate filaments from rat spinal cord and optic nerve, developmental protein involved in morphogenesis of neurons [32]

Neuronal development and polarity [8], cone collapse and cell migration; one of major determinants in the control of oxidative stress [17]

deacetylase sirtuin-2

$\begin{array}{ll}\text { Alpha-synuclein } & \text { Up-regulated Cytoplasm } \\ \text { Peroxiredoxin-2 } & \text { Up-regulated Cytoplasm }\end{array}$

Neuronal development and regulation

Colocalizes with microtubules; NAD-dependent deacetylase, involved in the control of mitotic exit in the cell cycle; up-regulation may protect the brain against incurred oxidative damage [33]

Neuronal development and regulation

Specifically expressed in neuronal cell bodies and synapses, negative regulation of neuron apoptosis, aging; role in the pathogenesis of Parkinson's disease [34]

Involved in redox regulation of the cell, negative regulation of neuron apoptosis; the relative abundance appears to protect cellular components by removing the low levels of hydroperoxides and peroxinitrites produced as a result of normal cellular metabolism in the cytosol [35]

Transitional endoplasmic Up-regulated Cytoplasm reticulum ATPase

\section{Nucleus}

Cellular development and regulation

Metabolism

$\begin{array}{ll}\text { Up-regulated } & \begin{array}{l}\text { Mitochondrion } \\ \text { matrix }\end{array} \\ \text { Up-regulated Mitochondrion } & \text { Metabolism }\end{array}$

dehydrogenase 1,

mitochondrial

Succinyl-CoA:3-ketoacidcoenzyme A transferase 1 , mitochondrial

Aspartate
aminotransferase,
mitochondrial

Downregulated

Mitochondrion matrix

\section{Ubiquitin carboxyl- terminal hydrolase isozyme L1}

Prohibitin

Down-
regulated

Cytoplasm Endoplasmatic reticulum membrane

Up-regulated Mitochondrion inner membrane

\section{Deubiquitination} Neuronal development and regulation

Metabolism

Cellular development and regulation
Involved in the formation of the transitional endoplasmatic reticulum, necessary for the fragmentation of Golgi stacks during mitosis and for their reassembly after mitosis [36]; interacts with neurofibromin to control the density of dendritic spines [37]

Glutamate catabolic process, long-term memory, in rat brain the glutamate dehydrogenase reaction operates in the direction of ammonia production [38]

A mitochondrial ketone body-activating enzyme [39]; brain development, response to drug

Amino acid metabolism, metabolite exchange between mitochondria and cytosol, fatty acid transport; its activity is related with the maintenance of amino acid homeostasis and might be an indicator of mitochondrial injury [40]

Involved both in the processing of ubiquitin precursors and of ubiquitinated proteins; the ubiquitination/proteasome pathway involved in synaptic plasticity [41]

Antiproliferative activity, role in regulating mitochondrial respiration activity and aging, response to drug [42-44]; down-regulation of prohibitin renders neurons more vulnerable to injury and reactive oxygen species production, whereas up-regulation appears to be neuroprotective [45]

\section{Coronin-1A}

Down-

Cytoplasm

regulated
Cellular development and regulation
Invagination of plasma membrane, forming protrusions of plasma membrane involved in cell locomotion; coronin-1A activity is spatially and temporally regulated by phosphoinositides [46] 
Table 2 Functional significance of proteins identified in PM fraction as altered by chronic morphine (Continued)

\begin{tabular}{|c|c|c|c|c|}
\hline Septin-11 & Up-regulated & Cytoplasm & $\begin{array}{l}\text { Cellular development } \\
\text { and regulation }\end{array}$ & $\begin{array}{l}\text { Filament-forming cytoskeletal GTPase, cell division; it is } \\
\text { involved in dendritic maturation [47] }\end{array}$ \\
\hline Myelin basic protein $\mathrm{S}$ & $\begin{array}{l}\text { Down- } \\
\text { regulated }\end{array}$ & Myelin membrane & $\begin{array}{l}\text { Neuronal } \\
\text { development and } \\
\text { regulation }\end{array}$ & $\begin{array}{l}\text { Myelination, negative regulation of axonogenesis; morphine } \\
\text { exposure colud result in a decreased number of myelinated } \\
\text { axons [48] }\end{array}$ \\
\hline $\begin{array}{l}605 \text { ribosomal protein } \\
\text { L12 }\end{array}$ & $\begin{array}{l}\text { Down- } \\
\text { regulated }\end{array}$ & Cytoplasm & Regulatory & $\begin{array}{l}\text { Binds directly to } 26 \mathrm{~S} \text { ribosomal RNA; it accesses the } \\
\text { importin } 11 \text { pathway as a major route into the nucleus [49] }\end{array}$ \\
\hline
\end{tabular}

MOR-stimulated $\left[{ }^{35} \mathrm{~S}\right] \mathrm{GTP} Y \mathrm{~S}$ binding after chronic heroin administration [53,54]. Accordingly, our analysis of PM isolated from cerebral cortex of rats exposed to morphine for 10 days $(10-50 \mathrm{mg} / \mathrm{kg})$ indicated significant desensitization of G-protein response to MOR and DOR stimulation [11] and up-regulation of ACI and II [12].

Proteome changes after prolonged morphine exposure have been so far investigated in "frozen tissue powders" of the rat cerebral cortex, hippocampus, striatum [55,56] and nucleus accumbens [7] or in the "whole-cell lysates" of striatal neuronal cell cultures [57]. Therefore, the aim of our work was to perform proteomic analysis in more defined preparations: post-nuclear supernatant (PNS) and membranes isolated in Percoll $^{\bullet}$ gradient (PM). The morphineinduced changes in protein composition (proteom) of PNS and PM were determined by 2D-electrophoresis resolution and PDQuest analysis; the altered proteins were identified by MALDI-TOF MS/MS or LC-MS/MS.
Proteomic analysis of PNS indicated a marked increase of proteins of mitochondrial and cytoplasmic origin (Additional file 1: Table S1 and Table 1). The 9 out of 10 proteins exhibiting the largest morphine-induced change in Coomassie stained gels were increased by morphine: 1-Guanine deaminase, $\uparrow 2.5 \times$; 2-Vacuolar-type proton ATP subunit B, brain isoform $\uparrow 2.6 \times$; 3-Protein disulfideisomerase $\mathrm{A} 3$, $\uparrow 3.4 \times$; 4-Dihydropyrimidinase-related protein 2 , $\uparrow 3.6 x ; 5-N$-ethylmaleimide sensitive fusion protein, isoform CRAa, $\uparrow 2.0 \times$; 6-Malate dehydrogenase, mitochondrial precursor, $\uparrow 1.4 \times$; 7-Glyceraldehyde-3-phosphate dehydrogenase, $\uparrow 1.6 \times$; 8-Aldolase $\mathrm{A}, \uparrow 1.3 \times$; 10-Aconitate hydratase, mitochondrial precursor, $\uparrow 1.3 \times$. The 4 out of 9 up-regulated proteins $(\mathbf{4}, \mathbf{6}, 7, \mathbf{1 0})$ were described as functionally related to manifestation of oxidative stress conditions [17,19,21,26]. Marked increase of Protein disulfide-isomerase A3 (3) causing apoptotic cell death [15] should be also noticed. The role in apoptosis has

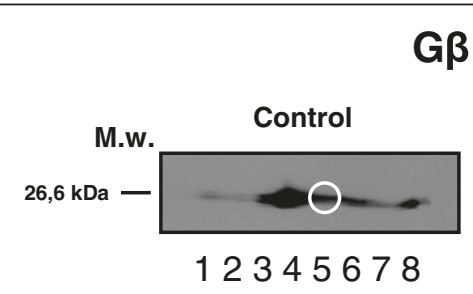

subunit

A
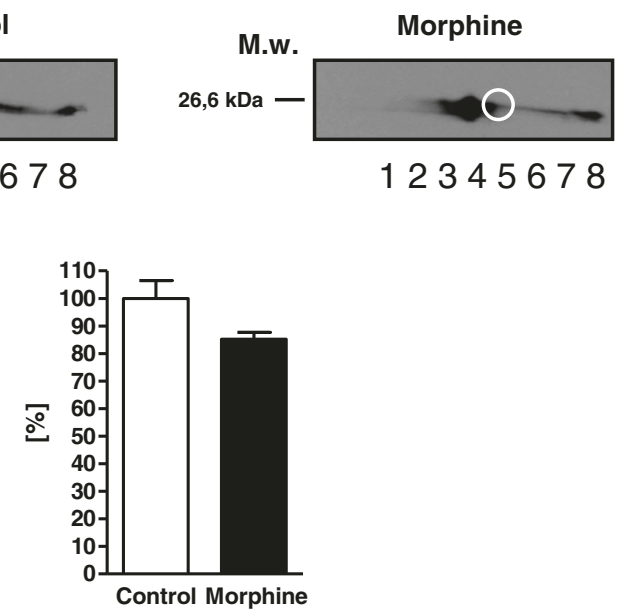

Figure $3 \mathrm{G} \beta$ subunit protein; immunoblot analysis of 2D-gels. A Two-dimensional resolution of G 3 protein content in PM isolated from control and morphine-adapted rats. PM protein $(400 \mu \mathrm{g})$ was resolved by 2D electrophoresis using the pl range 3-11 for isoelectric focusing in the first dimension. The white small circle shows the small fraction of the the total signal of $\mathrm{G} \beta$ which was taken into consideration when analyzed by LC-MS/MS. The second dimension was performed by SDS-PAGE in 10\% w/v acrylamide/0.26\% bis-acrylamide gels (Hoefer SE 600). $\mathrm{G} \beta$ was identified by immunoblotting with specific antibody as described in Material and methods. The numbers 1-8 represent spots of $\mathrm{G} \beta$ subunits which were subsequently analyzed by LC-MS/MS. B The average of 3 immunoblots \pm SEM. Difference between ( $-M 10)$ and (+M10) was analyzed by Student's t-test using GraphPadPrizm4 and found not significant, NS ( $p>0.05)$. 
Table 3 Proteomic analysis of G $\beta$ subunits isolated from brain cortex of control and morphine-treated rats

\begin{tabular}{|c|c|c|c|c|c|c|c|c|}
\hline Spot & $\begin{array}{l}\text { Accession } \\
\text { number }\end{array}$ & Protein name & $\begin{array}{l}\text { Mascot } \\
\text { score }\end{array}$ & $\begin{array}{l}\text { Matched } \\
\text { peptides }\end{array}$ & Peptides & $\begin{array}{l}\mathrm{SC}^{\mathrm{a}} \\
{[\%]}\end{array}$ & $\begin{array}{l}\mathrm{MW}^{\mathrm{b}} \\
(\mathrm{kDa})\end{array}$ & $\mathrm{pl}^{\mathrm{c}}$ \\
\hline \multirow[t]{6}{*}{3} & GBB1_RAT & Guanine nucleotide-binding protein & 184.3 & 6 & R.LFDLR.A & 16.8 & 37.4 & 5.6 \\
\hline & & subunit beta- 1 & & & R.LLVSASQDGK.L & & & \\
\hline & & & & & K.LWDVR.E & & & \\
\hline & & & & & K.IYAMHWGTDSR.L + Oxidation (M) & & & \\
\hline & & & & & K.ACADATLSQITNNIDPVGR.I & & & \\
\hline & & & & & K.VHAIPLR.S & & & \\
\hline \multirow[t]{12}{*}{4} & GBB1_RAT & Guanine nucleotide-binding protein & 471 & 12 & K.ACADATLSQITNNIDPVGR.I & 32.9 & 37.4 & 5.6 \\
\hline & & subunit beta-1 & & & R.LFVSGACDASAK.L & & & \\
\hline & & & & & K.IYAMHWGTDSR.L + Oxidation (M) & & & \\
\hline & & & & & R.LFDLR.A & & & \\
\hline & & & & & K.IYAMHWGTDSR.L & & & \\
\hline & & & & & R.LLVSASQDGK.L & & & \\
\hline & & & & & K.LWDVR.E & & & \\
\hline & & & & & R.KACADATLSQITNNIDPVGR.I & & & \\
\hline & & & & & R.LLLAGYDDFNCNVWDALK.A & & & \\
\hline & & & & & K.VHAIPLR.S & & & \\
\hline & & & & & K.LIIWDSYTTNK.V & & & \\
\hline & & & & & R.ELAGHTGYLSCCR.F & & & \\
\hline \multirow[t]{10}{*}{4} & GBB2_RAT & Guanine nucleotide-binding protein & 413.9 & 10 & R.TFVSGACDASIK.L & 14.4 & 37.3 & 5.6 \\
\hline & & subunit beta-2 & & & K.ACGDSTLTQITAGLDPVGR.I & & & \\
\hline & & & & & K.IYAMHWGTDSR.L + Oxidation (M) & & & \\
\hline & & & & & R.LFDLR.A & & & \\
\hline & & & & & K.IYAMHWGTDSR.L & & & \\
\hline & & & & & R.LLVSASQDGK.L & & & \\
\hline & & & & & K.LWDVR.D & & & \\
\hline & & & & & K.VHAIPLR.S & & & \\
\hline & & & & & K.LIIWDSYTTNK.V & & & \\
\hline & & & & & R.LLLAGYDDFNCNIWDAMK.G + Oxidation (W) & & & \\
\hline \multirow[t]{5}{*}{5} & GBB1_RAT & Guanine nucleotide-binding protein & 199.1 & 5 & R.AGVLAGHDNR.V & 14.1 & 37.4 & 5.6 \\
\hline & & subunit beta-1 & & & R.LFVSGACDASAK.L & & & \\
\hline & & & & & R.LFDLR.A & & & \\
\hline & & & & & K.IYAMHWGTDSR.L + Oxidation (M) & & & \\
\hline & & & & & R.LLVSASQDGK.L & & & \\
\hline \multirow[t]{5}{*}{5} & GBB2_RAT & Guanine nucleotide-binding protein & 188.7 & 5 & R.AGVLAGHDNR.V & 3.5 & 37.3 & 5.6 \\
\hline & & subunit beta-2 & & & R.TFVSGACDASIK.L & & & \\
\hline & & & & & R.LFDLR.A & & & \\
\hline & & & & & K.IYAMHWGTDSR.L + Oxidation (M) & & & \\
\hline & & & & & R.LLVSASQDGK.L & & & \\
\hline 7 & GBB (1-4)_RAT & $\begin{array}{l}\text { Guanine nucleotide-binding protein } \\
\text { subunit beta-3 }\end{array}$ & 22.4 & 1 & K.LLVSASQDGK.L & 2.9 & 37.2 & 5.4 \\
\hline 8 & GBB (1-4)_RAT & $\begin{array}{l}\text { Guanine nucleotide-binding protein } \\
\text { subunit beta-3 }\end{array}$ & 34.7 & 1 & K.LLVSASQDGK.L & 2.9 & 37.2 & 5.4 \\
\hline
\end{tabular}


been also described for Glyceraldehyde-3-phosphate dehydrogenase (7), already mentioned as major target protein in oxidative stress [21]. The 4 out of 9 up-regulated proteins $(\mathbf{4}, \mathbf{6}, 7, \mathbf{1 0})$ were thus functionally related to manifestation of the state of oxidative stress/oxidative damage in brain of morphine-exposed rats and 2 proteins were related to apoptotic cell death.

More detailed analysis of Percoll-purified membranes indicated a complex reorganization of PM protein composition. The list of proteins presented in Additional file 2: Table S2 and Table 2 indicates that morphine-induced alternation included increase as well as decrease of wide range of proteins functionally and structurally related to plasma, myelin, endoplasmic reticulum and mitochondrial membranes. Numerous soluble enzymes present in soluble, cytosol fraction or in mitochondrial matrix were also altered by chronic morphine. Surprisingly, with the exception of trimeric G $\beta$ subunit, not just one of these proteins was functionally related to GPCRor ionic-channel-activated signaling cascades. Similarly, proteomic analysis of protein alternations induced in the long-term TRH-treatment of HEK cells expressing TRH-R and G11 $\alpha$ protein indicated the change of 42 proteins, but not even one of these proteins represented plasma membrane protein functionally related to GPCR-initiated signaling cascades [58].

Our results indicate that the energy metabolism of rat brain cortex exposed to increasing doses of morphine $(10-50 \mathrm{mg} / \mathrm{kg}, 10$ days) is shifted far from the normal, physiological state. Using other words, brain cortex of rats exposed to morphine according to our protocol is far from being adapted. It may be suggested that the both neuronal and glial cells undergo a drastic reorganization as consequence of cell discomfort and, subsequently, oxidative stress. Simultaneous activation of all types of opioid receptors $(\mu-, \delta$ - and $\kappa-\mathrm{OR})$ by high doses of morphine results in high energy demand of neurons $[59,60]$. Consequently, glycogen in astrocytes as the single largest energy reserve in the brain is mobilized with the aim to match these increased energy requirements [61]. After depletion of glycogen in astrocytes, the state of oxidative stress appears [62] as the full supply of oxygen to brain mitochondria is not accompanied by transfer of the sufficient number of "reducing equivalents" into the mitochondrial matrix.

\section{Conclusions}

Proteomic analysis of rat brain cortex of rats exposed to morphine for 10 days $(10-50 \mathrm{mg} / \mathrm{kg})$ indicated a significant morphine-induced change of membrane protein composition. Changes in post-nuclear supernatant were exclusively based on increase (1.3-3.6x) of proteins of mitochondrial and cytoplasmic origin. In isolated plasma membranes (PM), morphine-induced alternation included increase as well as decrease of wide range of proteins functionally and structurally related to plasma, myelin, endoplasmic reticulum and mitochondrial membranes. Numerous soluble enzymes present in soluble, cytosol fraction or in mitochondrial matrix were also altered by chronic morphine. The only member of GPCRinitiated signaling cascades identified by LC-MS/MS in Percoll-purified membranes was trimeric G $\beta$ subunit (2-GBB) which was decreased $2 \mathrm{x}$ in samples prepared from morphine-adapted rats. This "active" component of $G \beta$ subunits, however, represented a minor pool of total complement of G $\beta$ molecules in PM, which was unchanged.

\section{Material and methods \\ Chemicals}

Acrylamide, bis-acrylamide and Coomassie Blue G-250 were from SERVA (Heidelberg, Germany), nitrocellulose membrane was from Whatman (Germany). Immobiline Dry-Strips, Pharmalyte buffer, and secondary anti-rabbit antibody labeled with horseradish peroxidase were purchased from GE Healthcare (Piscataway, NJ). Complete protease inhibitor cocktail was from Roche Diagnostic, Mannheim, Germany (cat. no. 1697498). All others chemicals were from Sigma-Aldrich and were of highest purity available. Primary antibody oriented against trimeric G $\beta$ subunit protein (T-20, sc-378) was from Santa Cruz.

\section{Animals}

Male Wistar rats (220-250 g) were killed by decapitation under ether narcosis, the frontal brain was rapidly removed, washed intensively from the remaining blood and cooled to $0^{\circ} \mathrm{C}$. The cerebral cortex was separated on the pre-cooled plate, snap frozen in liquid nitrogen and stored at $-70^{\circ} \mathrm{C}$ until use. The experiments were approved by Animal Care and Use Committee of the Institute of Physiology, Academy of Sciences of the Czech Republic to be in agreement with Animal Protection Law of the Czech Republic as well as European Comunity Council directives 86/609/EEC.

\section{Morphine treatment of experimental animals}

The animals were exposed to morphine by intra-muscular application according to the following protocol: $10 \mathrm{mg} / \mathrm{kg}$ (day 1 and 2), $15 \mathrm{mg} / \mathrm{kg}$ (day 3 and 4), $20 \mathrm{mg} / \mathrm{kg}$ (day 4 and 5), $30 \mathrm{mg} / \mathrm{kg}$ (day 6 and 7), $40 \mathrm{mg} / \mathrm{kg}$ (day 9) and, finally $50 \mathrm{mg} / \mathrm{kg}$ (day 10). The morphine-adapted rats were sacrificed 24 hours after the last dose of the drug (group + M10). Control animals were injected with sterile PBS and sacrificed in parallel with morphine-treated rats, i.e. 24 hours (group - M10) after the last dose [12]. 


\section{Subcellular fractionation of rat brain cerebral cortex preparation of post-nuclear supernatant (PNS) and percoll-purified membranes (PM)}

Rat brain cortex was minced with razor blade on precooled plate and diluted in STEM medium containing $250 \mathrm{mM}$ sucrose, $20 \mathrm{mM}$ Tris- $\mathrm{HCl}, 3 \mathrm{mM} \mathrm{MgCl}, 1 \mathrm{mM}$ EDTA, pH 7.6, fresh $1 \mathrm{mM}$ PMSF plus protease inhibitor cocktail. It was then homogenized mildly in loosely-fitting Teflon-glass homogenizer for $5 \mathrm{~min}(2 \mathrm{~g} \mathrm{w}$. w. per $10 \mathrm{ml})$ and centrifuged for $5 \mathrm{~min}$ at $3500 \mathrm{rpm}(1200 \times g)$. Resulting post-nuclear supernatant (PNS) was filtered through Nylon nets of decreasing size (330, 110 and 75 mesh, Nitex) and applied on top of Percoll in Beckman Ti70 tubes (30 ml of $27.4 \%$ Percoll in STE medium). Centrifugation for $60 \mathrm{~min}$ at $30000 \mathrm{rpm}(65000 \times g)$ resulted in the separation of two clearly visible layers (Bourova et al., 2009). The upper layer represented plasma membrane fraction (PM); the lower layer contained mitochondria (MITO). The upper layer was removed, diluted 1:3 in STEM medium and centrifuged in Beckman Ti70 rotor for $90 \mathrm{~min}$ at $50000 \mathrm{rpm}(175000 \times \mathrm{g})$. Membrane sediment was removed from the compact, gel-like sediment of Percoll and re-homogenized by hand in a small volume of $50 \mathrm{mM}$ Tris- $\mathrm{HCl}, 3 \mathrm{mM} \mathrm{MgCl}$, 1 mM EDTA, pH 7.4 (TME medium).

\section{SDS-PAGE and immunoblotting}

The aliquots of membrane fractions were mixed 1:1 with $2 x$ concentrated Laemmli buffer (SLB) and heated for $3 \mathrm{~min}$ at $95{ }^{\circ} \mathrm{C}$. Standard $(10 \% \mathrm{w} / \mathrm{v}$ acrylamide $/ 0.26 \% \mathrm{w} / \mathrm{v}$ bis-acrylamide) SDS electrophoresis was carried out as described before [63-65]. Molecular mass determinations were based on pre-stained molecular mass markers (Sigma, SDS 7B). After SDS-PAGE, proteins were transferred to nitrocellulose and blocked for $1 \mathrm{~h}$ at room temperature in $5 \%(\mathrm{w} / \mathrm{v})$ low-fat milk in TBS-Tween buffer [10 mM Tris-HCl, pH 8.0, $150 \mathrm{mM} \mathrm{NaCl,} \mathrm{0.1 \%} \mathrm{(v/v)}$ Tween 20]. Antibodies were added in TBS-Tween containing $1 \%(\mathrm{w} / \mathrm{v})$ low-fat milk and incubated for at least $2 \mathrm{~h}$. The primary antibody was then removed and the blot washed extensively (3x10 min) in TBS-Tween. Secondary antibodies (donkey anti-rabbit IgG conjugated with horseradish peroxidase) were diluted in TBS-Tween containing $1 \%(\mathrm{w} / \mathrm{v})$ low-fat milk, applied for $1 \mathrm{~h}$ and after three 10 min washes, the blots were developed by ECL technique using Super Signal West Dura (Pierce) as substrate. The developed blots were scanned with an imaging densitometer ScanJett 5370C (HP) and quantified by Aida Image Analyzer v. 3.28 (Ray test).

\section{Sample preparation for isoelectric focusing}

Samples of PNS or PM containing 400-600 $\mu \mathrm{g}$ protein or $2 \mathrm{mg}$ protein, respectively, were precipitated with ice cold aceton overnight at $-20^{\circ} \mathrm{C}$. After centrifugation at
$16000 \times g$ for $20 \mathrm{~min}$ at $4^{\circ} \mathrm{C}$, the supernatant was removed and the pellet was precipitated with ice-cold $6 \%$ TCA for $1.5 \mathrm{~h}$ on ice. After centrifugation at $16000 \times g$ for $10 \mathrm{~min}$ at $4{ }^{\circ} \mathrm{C}$, the supernatant was discarded and the pellet washed with $400 \mu \mathrm{l}$ of ice-cold $96 \%$ ethanol for $1 \mathrm{~h}$ at room temperature. The mixture was centrifuged at $16000 \times g$ for $10 \mathrm{~min}$ at $4{ }^{\circ} \mathrm{C}$ and the remaining pellet was solubilizated with $250 \mu \mathrm{l}$ IEF sample buffer containing $7 \mathrm{M}$ urea, $2 \mathrm{M}$ thiourea, 4\% CHAPS, $1 \%$ DTT, $1 \%$ ampholines $\mathrm{pH} 3-10$ and $0.01 \%$ bromphenol blue for $3 \mathrm{~h}$ at room temperature. After a brief centrifugation $(16000 \times g, 1 \mathrm{~min})$, the sample was transferred into a groove of the Immobiline DryStrip Reswelling Tray (GE Healthcare).

\section{Two-dimensional electrophoresis (2D-ELFO)}

Immobiline DryStrips (linear $\mathrm{pH}$ gradient 3-11 NL, $13 \mathrm{~cm}$ ) were placed into the Immobiline DryStrip Reswelling Tray containing protein samples and rehydrated overnight.

Isoelectric focusing was performed using the Multiphor II system (GE Healthcare) at $15^{\circ} \mathrm{C}$ in the following manner: $150 \mathrm{~V}$ for $5 \mathrm{~h}, 500 \mathrm{~V}$ for $1 \mathrm{~h}, 3500 \mathrm{~V}$ for $12 \mathrm{~h}$ and $500 \mathrm{~V}$ for $3 \mathrm{~h}$. The focused strips were stored at $20^{\circ} \mathrm{C}$ or immediately used.

Strips were rinsed thoroughly with ultrapure water, dried quickly on filter paper and equilibrated in $4 \mathrm{ml}$ of equilibration buffer $(50 \mathrm{mM}$ Tris- $\mathrm{HCl} \mathrm{pH}$ 6.8, $6 \mathrm{M}$ urea, $0.1 \mathrm{mM}$ EDTA, 2\% SDS, 30\% glycerol and 0.01\% bromophenol blue) containing 1\% DTT for 15 min in order to reduce disulphide bridges and other oxidized groups. Subsequently, the strips were alkylated in equilibration buffer containing $2.5 \%$ iodoacetamide for $15 \mathrm{~min}$. Molecular weight markers were loaded onto a piece of filter paper and placed close to the alkaline side of the strip. The strip and molecular marker were covered with $0.5 \%$ agarose. Gels were run vertically at a constant current of $10 \mathrm{~mA}$ for $20 \mathrm{~min}$ and then at $80 \mathrm{~mA}$ for $2 \mathrm{~h}$ till the bromophenol blue dye reached the end of the gel. The apparatus was cooled to $15^{\circ} \mathrm{C}$ using the Hoefer SE 600 unit (GE Healthcare).

\section{Silver staining}

Silver staining was performed by ProteoSilver $^{\mathrm{TM}}$ Plus Silver Stain Kit (Sigma-Aldrich) according to the manufacturer's instructions [66-68]. Briefly, the gel was fixed in $40 \%$ ethanol $/ 10 \%$ acidic acid overnight and then washed by $30 \%$ ethanol for $10 \mathrm{~min}$ and once by ultrapure water for $10 \mathrm{~min}$. The gels were incubated for $10 \mathrm{~min}$ with $1 \%$ Sensitizer solution and washed twice with $200 \mathrm{ml}$ of ultrapure water for $10 \mathrm{~min}$. The gels were submerged in $1 \%$ Silver solution for $10 \mathrm{~min}$, washed with $200 \mathrm{ml}$ of ultrapure water for $1 \mathrm{~min}$ and developed with $100 \mathrm{ml}$ of the Developer solution until the desired 
intensity of spots was attained. The ProteoSilver Stop solution was added to the Developer solution and gels were incubated for $5 \mathrm{~min}$. All steps were carried out at room temperature on an orbital shaker at 60 to $70 \mathrm{rpm}$. The gels were stored in fresh, ultrapure water or dried in $3 \%$ glycerol $/ 25 \%$ methanol.

\section{Colloidal coomassie staining}

For MS analysis, the gels were stained by colloidal Coomassie Blue G-250 [69]. The gel was fixed in 40\% methanol/5\% orthophosphoric acid for $12 \mathrm{~h}$ and incubated with colloidal Coomassie Blue (17\% ammonium sulphate, $34 \%$ methanol, $3 \%$ orthophosphoric acid and $0.1 \%$ Coomassie G-250) for $48 \mathrm{~h}$. After staining, the gels were kept in $1 \%$ acetic acid at $4^{\circ} \mathrm{C}$.

\section{Image analysis}

The stained 2D gels were scanned with an imaging densitometer ScanJett 5370C (HP) and quantified by PDQuest software (Bio-Rad, version 7.3.1). The process included spot detection, gel matching and spot quantification. Master gel was constructed as a synthetic image that contains the spot data from all the gels in the MatchSet. At least four replicates were performed for each sample. All matched and unmatched spots were then checked in a manual manner. Protein levels altered at least two-fold were taken into consideration.

Preparation of samples for MALDI-TOF MS/MS; analysis of post-nuclear fraction

Mass spectrometric analysis MALDI-TOF was performed as described before [58]. The peak lists from the MS spectra were generated by 4000 Series Explorer V 3.5.3 (Applied Biosystems/MDS Sciex) without smoothing, peaks with local signal to noise ratio greater than 5 were picked and searched by local Mascot v. 2.1 (Matrix Science) against nonredundant NCBI database of protein sequences (11186807 sequences; 3815639892 residues). Database search criteria were as follows-enzyme: trypsin, taxonomy: Rattus norvegicus (66703 sequences), fixed modification: carbamidomethylation, variable modification: methionine oxidation, peptide mass tolerance: $120 \mathrm{ppm}$, one missed cleavage allowed. Only hits that were scored as significant $(\mathrm{P}<0.001)$ were included.

\section{In-gel digestion and preparation of samples for LC-MS/} MS; analysis of percoll-purified membranes (PM)

Protein spots (from 2-DE: ca 1-2 $\mathrm{mm}$ in diameter) were excised from the Coomassie-stained gels, and then processed as described by Shevchenko et al. [70]. Briefly, the spots were first destained by incubation in $100 \mu \mathrm{l}$ of $100 \mathrm{mM}$ ammonium bicarbonate/acetonitrile (1:1, v/v) with occasional shaking for 1 hour. After destaining, the gel pieces were shrunk by dehydration in $500 \mu \mathrm{l}$ of acetonitrile, which was then removed and the gel pieces were dried in a vacuum centrifuge. In further step, $100 \mu \mathrm{l}$ of $10 \mathrm{mM}$ DTT in $100 \mathrm{mM}$ ammonium bicarbonate was added, and the proteins were reduced for 1 hour at $56^{\circ} \mathrm{C}$. After cooling to room temperature, the DTT solution was replaced by roughly the same volume of $55 \mathrm{mM}$ iodoacetamide in $100 \mathrm{mM}$ ammonium bicarbonate, and the gels were incubated at ambient temperature for $45 \mathrm{~min}$ in the dark. Then the gel pieces were washed with $100 \mu \mathrm{l}$ of $100 \mathrm{mM}$ ammonium bicarbonate, and dehydrated by addition $500 \mu \mathrm{l}$ of acetonitrile. Subsequently, the liquid phase was removed and the gel pieces were dried in a vacuum centrifuge.

Before the in-gel digestion, the gel pieces were cooled in an ice-cold bath and swollen in a $100 \mu \mathrm{l}$ of digestion buffer containing trypsin $(20 \mu \mathrm{g} / \mathrm{ml})$ in $50 \mathrm{mM}$ ammonium bicarbonate, and the gel pieces were sonicated (5 min), placed to air circulation thermostat, and incubated overnight at $37^{\circ} \mathrm{C}$. The volumes of solutions needed for processing of the protein bands were fourfold larger than the volumes for processing of the spots. The supernatant of each spot was then transferred to a new vial. The in-gel digestion was performed once more the same way. The resulting tryptic peptides were extracted with sonication (15 $\mathrm{min}$ ) by $150 \mu \mathrm{l}$ of extraction buffer ( $5 \%$ formic acid/acetonitrile, 1:2, v/v). Then the solution was spun, the supernatants were transferred, pooled and concentrated to dryness by lyophilization. Dried extracts were stored at $-80^{\circ} \mathrm{C}$ before analysis.

\section{Analysis of tryptic digests with LC-MS/MS}

Dried protein digests were dissolved in $20 \mu \mathrm{l}$ of $1 \%$ formic acid, centrifuged $\left(10000 \times g, 5 \mathrm{~min}, 4^{\circ} \mathrm{C}\right)$ and the supernatant transferred to inserts in vials. The nano-HPLC apparatus used for protein digests analysis was a Proxeon Easy-nLC (Proxeon, Odense, Denmark) coupled to a maXis Q-TOF (quadrupole - time of flight) mass spectrometer with ultrahigh resolution (Bruker Daltonics, Bremen, Germany) by nanoelectrosprayer. The nLC-MS/ MS instruments were controlled with the software packages HyStar 3.2 and micrOTOF-control 3.0. The data were collected and manipulated with the software packages ProteinScape 2.0 and DataAnalysis 4.0 (Bruker Daltonics).

The $3 \mu$ l of the peptide mixture were injected into a NSAC-11-C18 Biosphere C18 column (particle size: $5 \mu \mathrm{m}$, pore size: $12 \mathrm{~nm}$, length: $150 \mathrm{~mm}$, inner diameter: $75 \mu \mathrm{m}$ ), with a NS-MP-10 Biosphere C18 pre-column (particle size: $5 \mu \mathrm{m}$, pore size: $12 \mathrm{~nm}$, length: $20 \mathrm{~mm}$, inner diameter: $100 \mu \mathrm{m}$ ), both manufactured by NanoSeparations (Nieuwkoop, Netherlands).

The separation of peptides was achieved via a linear gradient between mobile phase A (water) and B (acetonitrile), both containing $0.1 \%(\mathrm{v} / \mathrm{v})$ formic acid. Separation was 
started by running the system with $5 \%$ mobile phase $\mathrm{B}$, followed by gradient elution to $30 \% \mathrm{~B}$ at $70 \mathrm{~min}$. The next step was gradient elution to $50 \%$ B in $10 \mathrm{~min}$, and then a gradient to $100 \%$ B in 8 min was used. Finally, the column was eluted with $100 \%$ B for 2 min. Equlibration before the next run was achieved by washing the column with $5 \%$ mobile phase $B$ for $10 \mathrm{~min}$. The flow rate was $0.25 \mu \mathrm{l} \mathrm{min}{ }^{-1}$, and the column was held at ambient temperature $\left(25^{\circ} \mathrm{C}\right)$.

On-line nano-electrospray ionization (easy nano-ESI) in positive mode was used. The ESI voltage was set at +4.5 kV, scan time $1.3 \mathrm{~Hz}$. Operating conditions: drying gas $\left(\mathrm{N}_{2}\right), 1 \mathrm{l} \mathrm{min}^{-1}$; drying gas temperature, $160^{\circ} \mathrm{C}$; nebulizer pressure, 0.4 bar. Experiments were performed by scanning from 100 to $2200 \mathrm{~m} / \mathrm{z}$. The reference ion used (internal mass lock) was a monocharged ion of $\mathrm{C}_{24} \mathrm{H}_{19} \mathrm{~F}_{36} \mathrm{~N}_{3} \mathrm{O}_{6} \mathrm{P}_{3}(\mathrm{~m} / z$ 1221.9906). Mass spectra corresponding to each signal from the total ion current chromatogram were averaged, enabling an accurate molecular mass determination. All LC-MS/MS analyses were done in duplicates.

\section{Database searching}

Data were processed using ProteinScape software. Proteins were identified by correlating tandem mass spectra to SwissProt databases, using the MASCOT searching engine (http://www.matrixscience.com); Rattus norvegicus as species. Trypsin was chosen as the enzyme parameter. One missed cleavage was allowed, and an initial peptide mass tolerance of $\pm 10.0 \mathrm{ppm}$ was used for MS and $\pm 0.05 \mathrm{Da}$ for MS/MS analysis. Cysteines were assumed to be carbamidomethylated, proline and lysine to be hydroxylated, serine, threonine and tyrosine to be phosphorylated, and methionine was allowed to be oxidated. All these possible modifications were set to be variable. Monoisotopic peptide charge was set to $1+, 2+$ and $3+$. The Peptide Decoy option was selected during the data search process to remove false-positive results. Only significant hits (MASCOT score $\geq 60$, http://www. matrixscience.com) were accepted.

\section{Statistical analysis}

In immunoblot assays, the significance of difference between data collected in control and morphine-treated samples was analyzed by Student's $t$-test by GraphPadPrizm4. Results represent the average \pm S.E.M.

\section{Protein determination}

The method of Lowry was used for determination of membrane protein. Bovine serum albumin (Sigma, Fraction V) was used as standard. Data were calculated by fitting the data with calibration curve as quadratic equation.

\section{Additional files}

Additional file 1: Table S1. Proteomic analysis of post-nuclear supernatant prepared from brain cortex of control and morphine-treated rats

Additional file 2: Table S2. Proteomic analysis of PM fraction isolated from brain cortex of control and morphine-treated rats.

\section{Abbreviations}

AC: Adenylyl cyclase; CBB: Coomassie brilliant blue; d: Day; DAMGO: [(2-Dalanine2-4-methylphenylalanine-5-glycineol)-enkefalin]; DADLE: [(2-D-alanine5-D-leucine)-enkefalin]; DOR: $\delta$-opioid receptor; DTT: Dithiothreitol; EDTA: Ethylenediamine-tetraacetic acid; ELFO: Electrophoresis; GPCR $G$ protein-coupled receptor; $G$ proteins: Heterotrimeric guanine nucleotide-binding regulatory proteins; CHAPS: 3-[(3-cholamidopropyl) dimethylammonio]-1-propanesulfonate; DTT: Dithiothreitol; IEF: Isoelectric focusing; KOR: K-opioid receptor; LC-MS/MS: Liquid chromatography-mass spectrometry; MALDI-TOF MS/MS: Matrix-assisted laser desorption/ionization time-of-flight mass spectrometry; MOR: $\mu$-opioid receptor; PBS: Phosphate-buffered saline; PM: Percoll ${ }^{\circledR}$-purified membranes;

PMSF: Phenylmethylsulfonyl fluoride; PNS: Post-nuclear supernatant; SLB: Sample loading buffer; TBS: Tris-buffered saline; w.w.: Wet weight; TCA: Trichloroacetic acid; TRH-R: Thyrotropin-releasing hormone receptor.

\section{Competing interests}

The authors declare that they have no competing interests.

\section{Authors' contributions}

$\mathrm{HU}$ performed the experiments, analyzed the data and participated in writing the manuscript. AE performed proteomic analysis of plasma membrane proteins by LC-MS/MS. DK and LB were responsible for application of morphine to rats according to experimental protocol described in Methods and prepared membrane fractions by differential or density gradient centrifugation. PS conceived the study, designed the experiments and wrote the manuscript. All authors have read and approved the final manuscript.

\section{Acknowledgements}

This work was supported by the GACR (P207/12/0919), Centrum of Neurosciences (P304/12/G069) and by Academy of Sciences of the Czech Republic (RVO: 67985823). The authors thank to Silvia Bezouskova for useful practical experience, Petr Jedelsky for performing MALDI -TOF MS/MS and Karel Harant for valuable assistance.

\section{Author details}

${ }^{1}$ Laboratories of Biochemistry of Membrane Receptors, Institute of Physiology, v.v.i., Academy of Sciences of the Czech Republic, Videnska 1083, Prague 4 14220, Czech Republic. ${ }^{2}$ Analysis of Biologically Important Compounds, Institute of Physiology, v.v.i., Academy of Sciences of the Czech Republic, Videnska 1083, Prague 4 14220, Czech Republic.

Received: 2 July 2013 Accepted: 3 February 2014 Published: 14 February 2014

\section{References}

1. Contet C, Kieffer BL, Befort K: Mu opioid receptor: a gateway to drug addiction. Curr Opin Neurobiol 2004, 14:370-378.

2. Preston KL: Drug abstinence effects: opioids. Br J Addict 1991, 86:1641-1646.

3. Connor M, Christie MD: Opioid receptor signalling mechanisms. Clin Exp Pharmacol Physiol 1999, 26:493-499.

4. Law PY, Wong YH, Loh HH: Molecular mechanisms and regulation of opioid receptor signaling. Annu Rev Pharmacol Toxicol 2000, 40:389-430.

5. Law PY, Loh HH, Wei LN: Insights into the receptor transcription and signaling: implications in opioid tolerance and dependence. Neuropharmacology 2004, 47:300-311.

6. Robinson TE, Kolb B: Morphine alters the structure of neurons in the nucleus accumbens and neocortex of rats. Synapse 1999, 33:160-162. 
7. Li KW, Jimenez CR, van der Schors RC, Hornshaw MP, Schoffelmeer ANM, Smit $A B$ : Intermittent administration of morphine alters protein expression in rat nucleus accumbens. Proteomics 2006, 6:2003-2008.

8. Kim SY, Chudapongse N, Lee SM, Levin MC, Oh JT, Park HJ, Ho IK. Proteomic analysis of phosphotyrosyl proteins in morphine-dependent rat brains. Brain Res Mol Brain Res 2005, 133:58-70.

9. Miller AL, Hawkins RA, Harris RL, Veech RL: The effects of acute and chronic morphine treatment and of morphine withdrawal on rat brain in vivo. Biochem J 1972, 129:463-469.

10. Li Q, Zhao X, Zhong LJ, Yang HY, Wang Q, Pu XP: Effects of chronic morphine treatment on protein expression in rat dorsal root ganglia. Eur J Pharmacol 2009, 612:21-28.

11. Bourova L, Vosahlikova M, Kagan D, Dlouha K, Novotny J, Svoboda P: Longterm adaptation to high doses of morphine causes desensitization of $\mu$ OR- and $\delta$-OR-stimulated G-protein response in forebrain cortex but does not decrease the amount of G-protein alpha subunit. Med Sci Monit 2010, 16:260-270.

12. Ujcikova H, Dlouha K, Roubalova L, Vosahlikova M, Kagan D, Svoboda P: Up-regulation of adenylylcyclases I and II induced by long-term adaptation of rats to morphine fades away 20 days after morphine withdrawal. Biochim Biophys Acta 1810, 2011:1220-1229.

13. Paletzki RF: Cloning and characterization of guanine deaminase from mouse and rat brain. Neuroscience 2002, 109:15-26.

14. Toei M, Saum R, Forgac M: Regulation and isoform function of the $V$ ATPases. Biochemistry 2010, 49:4715-4723.

15. Tanaka S, Uehara T, Nomura Y: Up-regulation of protein-disulfide isomerase in response to hypoxia/brain ischemia and its protective effect against apoptotic cell death. J Bioch Chem 2000, 275:10388-10393.

16. Conn KJ, Gao W, MCKee A, Lan MS, Ullman MD, Eisenhauer PB, Fine RE, Wells JM: Identification of the protein disulfide isomerase family member PDIp in experimental Parkinson's disease and Lewy body pathology. Brain Res 2004, 1022:164-172.

17. Drabik A, Bierczynska-Krzysik A, Bodzon-Kulakowska A, Suder P, Kotlinska J, Silberring J: Proteomics in neurosciences. Mass Spectrom Rev 2007 26:432-450.

18. Abul-Husn NS, Annangudi SP, Ma'ayan A, Ramos-Ortolaza DL, Stockton SD Jr, Gomes I, Sweedler JV, Devi LA: Chronic morphine alter the presynaptic protein profile: identification of novel molecular targets using proteomics and network analysis. PLOS One 2011, 6:e25535.

19. Shi Q, Gibson GE: Up-regulation of the mitochondrial malate dehydrogenase by oxidative stress in mediated by miR-743a. J Neurochem 2011, 118:440-448.

20. Chuang DM, Hough C, Senatorov W: Glyceraldehyde-3-phosphate dehydrogenase, apoptosis, and neurodegenerative diseases. Annu Rev Pharmacol Toxicol 2005, 45:269-290.

21. Hwang NR, Yim SH, Kim YM, Jeong J, Song EJ, Lee Y, Choi S, Lee KJ: Oxidative modifications of glyceraldehyde-3-phophate dehydrogenase play a key role in its multiple cellular functions. Biochem J 2009, 423:253-264.

22. Koppitz B, Vogel F, Mayr GW: Mammalian aldolases are isomer-selective high-affinity inositol polyphosphate binders. Eur J Biochem 1986, 161:421-433.

23. Baron CB, Tolan DR, Choi KH, Coburn RF: Aldolase A Ins $(1,4,5) \mathrm{P}_{3}$-binding domains as determined by site-directed mutagenesis. Biochem J 1999, 341:805-812.

24. Hua LV, Green M, Warsh JJ, Li PP: Lithium regulation of aldolase A expression in the rat frontal cortex: identification by differential display. Biol Psychiatry 2000, 48:58-64

25. Shen W, Willis D, Zhang Y, Schlattner U, Wallimann T, Molloy GR: Expression of creatine kinase isoenzyme genes during postnatal development of rat brain cerebellum:evidence for transcriptional regulation. Biochem J 2002, 367:369-380.

26. Perluigi M, Poon HF, Maragos W, Pierce WM, Klein JB, Calabrese V, Cini C, De Marco C, Butterfield DA: Proteomic analysis of protein expression and oxidative modification in R6/2 transgenic mice. Mol Cell Proteomics 2005 4:1849-1861.

27. Kashihara M, Miyata S, Kumanogoh H, Funatsu N, Matsunaga W, Kiyohara T, Sokawa Y, Maekawa S: Changes in the localization of NAP-22, a calmodulin binding membrane protein, during the development of neuronal polarity. Neurosci Res 2000, 37:315-325.
28. Okae $H$, Iwakura $Y$ : Neural tube defects and impaired neural progenitor cell proliferation in G $\beta_{1}$-deficient mice. Dev Dyn 2010, 239:1089-1101.

29. Sunahara RK, Taussig R: Isoforms of mammalian adenylylcyclase: multiplicities of signaling. Mol Interv 2002, 2:168-184.

30. Wang HY, Burns LH: G $\beta$ Y that interacts with adenylyl cyclase in opioid tolerance originates from a Gs protein. J Neurobiol 2006, 12:1302-1310.

31. Perluigi M, Domenico FD, Giorgi A, Shininà ME, Coccia R, Cini C, Bellia F, Cambria MT, Cornelius C, Butterfield DA, Calabrese V: Redox proteomics in aging rat brain involvement of mitochondrial reduced glutathione status and mitochondrial protein oxidation in the aging process. J Neurosci Res 2010, 88:3498-3507

32. Kaplan MP, Chin SSM, Fliegner KH, Liem RKH: a-internexin, a novel neuronal intermediate filament protein, precedes the low molecular weight neurofilament protein (NF-L) in the developing rat brain. J Neurosci 1990, 10:2735-2748.

33. Wu A, Ying Z, Gomez-Pinilla F: Oxidative stress modulates Sir2a in rat hippocampus and cerebral cortex. Eur J Neurosci 2006, 22:5213-5216.

34. Maries E, Dass B, Collier TJ, Kordower JH, Steece-Collier K: The role of asynuclein in Parkinson's disease: insights from animal models. Nat Rev Neurosci 2003, 4:727-738.

35. Rhee SG, Chae HZ, Kim K: Peroxiredoxins: a historical overview and speculative preview of novel mechanisms and emerging concepts in cell signaling. Free Radic Biol Med 2005, 38:1543-1552.

36. Woodman PG: p97, a protein coping with multiple identities. J Cell Sci 2003, 116:4283-4290.

37. Wang HF, Shih YT, Chen CY, Chao HW, Lee MJ, Hsueh YP: Valosincontaining protein and neurofibromin interact to regulate dendritic spine density. J Clin Invest 2011, 121:4820-4837.

38. Cooper AJL: ${ }^{13} \mathrm{~N}$ as a tracer for studying glutamate metabolism. Neurochem Int 2011, 59:456-464.

39. Ohnuki M, Takahashi N, Yamasaki M, Fukui T: Different localization in rat brain of the novel cytosolic ketone body-utilizing enzyme, acetoacetyl-CoA synthetase, as compared to succinyl-CoA:3 -oxoacid CoA-transferase. Biochim Biophys Acta 2005, 1729:147-153.

40. Das SK, Hiran KR, Mukherjee S, Vasudevan DM: Oxidative stress is the primary event: effects of ethanol consumption in brain. Indian J Clin Biochem 2007, 22:99-104.

41. Murphey RK, Godenschwege TA: New roles for ubiquitin in the assembly and function of neuronal circuits. Neuron 2002, 36:5-8.

42. Artal-Sanz M, Tavernarakis N: Prohibitin couples diapause signalling to mitochondrial metabolism during ageing in C.elegans. Nature 2009, 461:793-797.

43. Merkwirth C, Langer T: Prohibitin function within mitochondria: essential roles for cell proliferation and cristae morphogenesis. Biochim Biophys Acta 2009, 1793:27-32.

44. Mishra S, Ande SR, Nyomba BL: The role of prohibitin in cell signaling. FEBS J 2010, 277:3937-3946.

45. Zhou P, Qian L, D'Aurelio M, Cho S, Wang G, Manfredi G, Pickel V, ladecola C: Prohibitin reduces mitochondrial free radical production and protects brain cells from different injury modalities. J Neurosci 2012, 32:583-592.

46. Tsujita K, Itoh T, Kondo A, Oyama M, Kozuka-Hata H, Irino Y, Hasegawa J, Takenawa T: Proteome of acidic phospholipid-binding proteins: spatial and temporal regulation of coronin $1 \mathrm{~A}$ by phosphoinositides. J Biol Chem 2010, 285:6781-6789.

47. Tada T, Simonetta A, Batterton M, Kinoshita M, Edbauer D, Sheng M: Role of septin cytoskeleton in spine morphogenesis and dendrite development in neurons. Curr Biol 2007, 17:1752-1758.

48. Traudt CM, Tkac I, Ennis KM, Sutton LM, Mammel DM, Rao R: Postnata morphine administration alters hippocampal development in rats. J Neurosci Res 2012, 90:307-314.

49. Plafker SM, Macara IG: Ribosomal protein L12 uses a distinct nuclear import pathway mediated by importin 11. Mol Cell Biol 2002, 22:1266-1275.

50. Filizola M, Devi LA: Structural biology: how opiod drugs bind to receptors. Nature 2012, 485:314-317.

51. Manglik A, Kruse AC, Kobilka TS, Thian FS, Mathiesen JM, Sunahara RK, Pardo L, Weis WI, Kobilka BK, Granier S: Crystal structure of the $\mu$-opioid receptor bound to a morphinan antagonist. Nature 2012, 485:321-326.

52. Sim L, Selley DE, Dworkin SI, Childers SR: Effects of chronic morphine administration on $\mu$ opioid receptor-stimulated $\left[{ }^{35} \mathrm{~S}\right] \mathrm{GTP} \gamma \mathrm{S}$ autoradiography in rat brain. J Neurosci 1996, 16:2684-2692 
53. Maher CE, Martin TJ, Childers SR: Mechanisms of mu opioid receptor/Gprotein desensitization in brain by chronic heroin administration. Life Sci 2005, 77:1140-1154.

54. Sim-Selley LJ, Selley DE, Vogt LJ, Childers SR, Martin TJ: Chronic heroin self-administration desensitizes $\mu$ opioid receptor-activated G-proteins in specific regions of rat brain. J Neurosci 2000, 20:4555-4562.

55. Bierczynska-Krzysik A, Bonar E, Drabik A, Noga M, Suder P, Dylag T, Dubin A, Kotlinska J, Silberring J: Rat brain proteome in morphine dependence. Neurochem Int 2006, 49:401-406.

56. Bierczynska-Krzysik A, Pradeep John JP, Silberring J, Kotlinska J, Dylag T, Cabatic M, Lubec G: Proteomic analysis of rat cerebral cortex, hippocampus and striatum after exposure to morphine. Int $J$ Mol Med 2006, 18:775-784.

57. Bodzon-Kułakowska A, Suder P, Mak P, Bierczynska-Krzysik A, Lubec G, Walczak B, Kotlinska J, Silberring J: Proteomic analysis of striatal neuronal cell cultures after morphine administration. J Sep Sci 2009, 32:1200-1210

58. Drastichova Z, Bourova L, Hejnova L, Jedelsky P, Svoboda P, Novotny J: Protein alterations induced by long-term agonist treatment of HEK293 cells expressing thyrotropin-releasing hormone receptor and $\mathrm{G}_{11} \mathrm{a}$ protein. J Cell Biochem 2010, 109:255-264.

59. Kraus MA, Piper JM, Kornetsky C: Persistent increases in basal cerebral metabolic activity induced by morphine sensitization. Pharmacol Biochem Behav 1997, 57:89-100.

60. Magistretti PJ, Pellerin L: Cellular mechanisms of brain energy metabolism and their relevance to functional brain imaging. Philos Trans $R$ Soc Lond $B$ Biol Sci 1999, 354:1155-1163.

61. Magistretti PJ, Allaman I: Glycogen: a Trojan horse for neurons. Nat Neurosci 2007, 10:1341-1342.

62. Guzman DC, Vazquez IE, Brizuela NO, Alvarez RG, Mejia GB, Garcia EH, Santamaria D, La Rosa De Apreza M, Olguin HJ: Assessment of oxidative damage induced by acute doses of morphine sulfate in postnatal and adult rat brain. Neurochem Res 2006, 31:549-554.

63. Matousek P, Novotny J, Svoboda P: Resolution of G(s)alpha and G(q)alpha/ $G(11) a l p h a$ proteins in membrane domains by two-dimensional electrophoresis: the effect of long-term agonist stimulation. Physiol Res 2004, 53:295-303.

64. Matousek P, Novotny J, Rudajev V, Svoboda P: Prolonged agonist stimulation does not alter the protein composition of membrane domains in spite of dramatic changes induced in a specific signaling cascade. Cell Biochem Biophys 2005, 42:21-40.

65. Moravcova Z, Rudajev V, Stohr J, Novotny J, Cerny J, Parenti M, Milligan G, Svoboda P: Long-term agonist stimulation of IP prostanoid receptor depletes the cognate $\mathrm{G}(\mathrm{s})$ alpha protein in membrane domains but does not change the receptor level. Biochim Biophys Acta 2004, 1691:51-65.

66. Gharahdaghi F, Weinberg CR, Meagher DA, Imai BS, Mische SM: Mass spectrometric identification of proteins from silver-stained polyacrylamide gel: a method for the removal of silver ions to enhance sensitivity. Electrophoresis 1999, 20:601-605.

67. Shevchenko A, Wilm M, Vorm O, Mann M: Mass spectrometric sequencing of proteins from silver-stained polyacrylamide gels. Anal Chem 1996 68:850-858

68. Sinha P, Poland J, Schnölzer M, Rabilloud T: A new silver staining apparatus and procedure for matrix-assisted laser desorption/ionizationtime of flight analysis of proteins after two-dimensional electrophoresis. Proteomics 2001, 1:835-840

69. Fountoulakis M, Takács MF, Berndt P, Langen H, Takács B: Enrichment of low abundance proteins of Escherichia coli by hydroxyapatite chromatography. Electrophoresis 1999, 20:2181-2195.

70. Shevchenko A, Tomas H, Havlis J, Olsen JV, Mann M: In-gel digestion for mass spectrometric characterization of proteins and proteomes. Nat Protoc 2006, 1:2856-2860.

doi:10.1186/1477-5956-12-11

Cite this article as: Ujcikova et al:: Proteomic analysis of post-nuclear supernatant fraction and percoll-purified membranes prepared from brain cortex of rats exposed to increasing doses of morphine. Proteome Science 2014 12:11.

\section{Submit your next manuscript to BioMed Central and take full advantage of:}

- Convenient online submission

- Thorough peer review

- No space constraints or color figure charges

- Immediate publication on acceptance

- Inclusion in PubMed, CAS, Scopus and Google Scholar

- Research which is freely available for redistribution

Submit your manuscript at www.biomedcentral.com/submit
C Biomed Central 